\title{
Biochemical and physiological bases for utilization of dietary amino acids by young Pigs
}

\author{
Reza Rezaei ${ }^{1}$, Weiwei Wang ${ }^{1,2}$, Zhenlong $\mathrm{Wu}^{2}$, Zhaolai Dai ${ }^{2}$, Junjun Wang ${ }^{2}$ and Guoyao $\mathrm{Wu}^{1,2^{*}}$
}

\begin{abstract}
Protein is quantitatively the most expensive nutrient in swine diets. Hence it is imperative to understand the physiological roles played by amino acids in growth, development, lactation, reproduction, and health of pigs to improve their protein nutrition and reduce the costs of pork production. Due to incomplete knowledge of amino acid biochemistry and nutrition, it was traditionally assumed that neonatal, post-weaning, growing-finishing, and gestating pigs could synthesize sufficient amounts of all "nutritionally nonessential amino acids" (NEAA) to support maximum production performance. Therefore, over the past 50 years, much emphasis has been placed on dietary requirements of nutritionally essential amino acids as building blocks for tissue proteins. However, a large body of literature shows that NEAA, particularly glutamine, glutamate, arginine and proline regulate physiological functions via cell signaling pathways, such as mammalian target of rapamycin, AMP-activated protein kinase, extracellular signal-related kinase, Jun kinase, mitogen-activated protein kinase, and NEAA-derived gaseous molecules (e.g., nitric oxide, carbon monoxide, and hydrogen sulfide). Available evidence shows that under current feeding programs, only $70 \%$ and $55 \%$ of dietary amino acids are deposited as tissue proteins in 14-day-old sow-reared piglets and in 30-day-old pigs weaned at 21 days of age, respectively. Therefore, there is an urgent need to understand the roles and dietary requirements of NEAA in swine nutrition. This review highlights the basic biochemistry and physiology of absorption and utilization of amino acids in young pigs to enhance the efficacy of utilization of dietary protein and to minimize excretion of nitrogenous wastes from the body.
\end{abstract}

Keywords: Amino acids, Metabolism, Nutrition, Pigs

\section{Introduction}

Amino acids have been traditionally categorized as either nutritionally essential (EAA) or non-essential (NEAA) in animals (Table 1). The EAA must be supplemented in the diet in adequate amounts because their carbon skeletons are not synthesized in vivo [1,2]. Alternatively, inter-organ metabolism of amino acids in the body leads to the de novo synthesis of NEAA [3,4]. For example, glutamine and glutamate released from skeletal muscle into the circulation derive their $\alpha$-amino nitrogen from branched-chain amino acids whose carbon skeletons cannot be formed in the body. Growing evidence shows that pigs do not synthesize sufficient amount of NEAA to maintain their maximum growth, development, lactation, and reproduction performance [5-7].

\footnotetext{
* Correspondence: g-wu@tamu.edu

'Department of Animal Science, Texas A\&M University, College Station, Texas 77843, USA

${ }^{2}$ State Key Laboratory of Animal Nutrition, China Agricultural University, Beijing 100193, China
}

\section{() Biomed Central

(c) 2013 Rezaei et al.; licensee BioMed Central Ltd. This is an Open Access article distributed under the terms of the Creative Commons Attribution License (http://creativecommons.org/licenses/by/2.0), which permits unrestricted use, distribution, and reproduction in any medium, provided the original work is properly cited.
Amino acids play crucial role in maintaining normal physiological function and nutritional status of the body $[8,9]$. Amino acids that regulate key metabolic pathways of cells essential for survival, growth, development, and reproduction of animals are recently proposed as the "functional amino acids" [3,10]. The term "functional amino acids" encompasses arginine, cysteine, glutamine, glutamate, glycine, leucine, proline, and tryptophan which are known to improve the efficiency of utilization of dietary proteins in pigs $[6,11,12]$.

Protein is quantitatively the most expensive nutrient in swine diets. Complex biochemical and physiological processes are required to transform food proteins into tissue proteins. These events include digestion, absorption, and metabolism of amino acids that involve enterocytes, the microbiota in the lumen of the small intestine, the splanchnic bed, digestive organs, and interorgan cooperation via multiple signaling pathways [3]. These complex processes form the fundamentals of 
Table 1 Traditional classification of AA as EAA and NEAA in swine nutrition

\begin{tabular}{ll}
\hline EAA & NEAA \\
\hline Arginine & Alanine \\
Histidine & Asparagine \\
Isoleucine & Aspartate \\
Leucine & Cysteine $^{2}$ \\
Lysine & Glutamate $^{2}$ \\
Methionine & Glutamine $^{2}$ \\
Phenylalanine & Glycine $^{2}$ \\
Threonine & Proline $^{2}$ \\
Tryptophan & Serine \\
Valine & Tyrosine \\
\hline
\end{tabular}

${ }^{1}$ Currently classified as an EAA for young pigs.

${ }^{2}$ Currently considered as conditionally essential amino acids. They are synthesized insufficiently by animals at certain developmental stages or under certain feeding conditions.

$E A A=$ nutritionally essential $A A$.

$N E A A=$ nutritionally nonessential $\mathrm{AA}$.

dynamic utilization of both EAA and NEAA (Figure 1). Except for glutamate, glutamine, and aspartate, which are extensively degraded in the small intestine, dietary amino acids are primarily used for protein accretion in young pigs [13]. Limited research has been conducted to understand the utilization of amino acids towards the synthesis of non-protein substances in animals. Based on these studies, it has been estimated that approximately $10-40 \%$ of dietary EAA and NEAA (e.g., asparagine, cysteine, serine, and tyrosine) that enter the portal circulation are degraded in extra-intestinal tissues [13].

Under current feeding programs, efficiency of the utilization of dietary proteins for animal growth remains suboptimal. For example, in 14-day-old pigs reared by sows and in 30-day-old pigs weaned at 21 days of age, only $70 \%$ and $55 \%$ of dietary amino acids are deposited in tissue proteins, respectively [13]. The remaining amino acids must be degraded to $\mathrm{CO}_{2}, \mathrm{NO}, \mathrm{CO}, \mathrm{H}_{2} \mathrm{~S}$, methane, $\mathrm{H}_{2} \mathrm{O}$, ammonia, urea, nitrate, and other nitrogenous metabolites $[14,15]$. Excretion of these products in urine and feces is a source of environmental pollution and can contribute to global climate changes. Therefore, there is an urgent need to better understand biochemical and physiological limitations to efficiency of amino acid utilization in swine.

\section{Dietary essentiality of amino acids in young pigs}

Amino acids are molecules that contain both amino and acid groups. Amino acids are the primary structural building units of proteins. They form short polymer chains, peptides or polypeptides, which subsequently lead to proteins. There are generally 20 different amino acids in protein structures. New findings about biochemical and molecular actions of amino acids have provided useful knowledge for designing new means to improve health and growth. Arginine, histidine, isoleucine, leucine, lysine, methionine, phenylalanine, threonine, tryptophan, and valine are nutritionally indispensable or essential amino acids for piglets. The pig cannot synthesize all of these

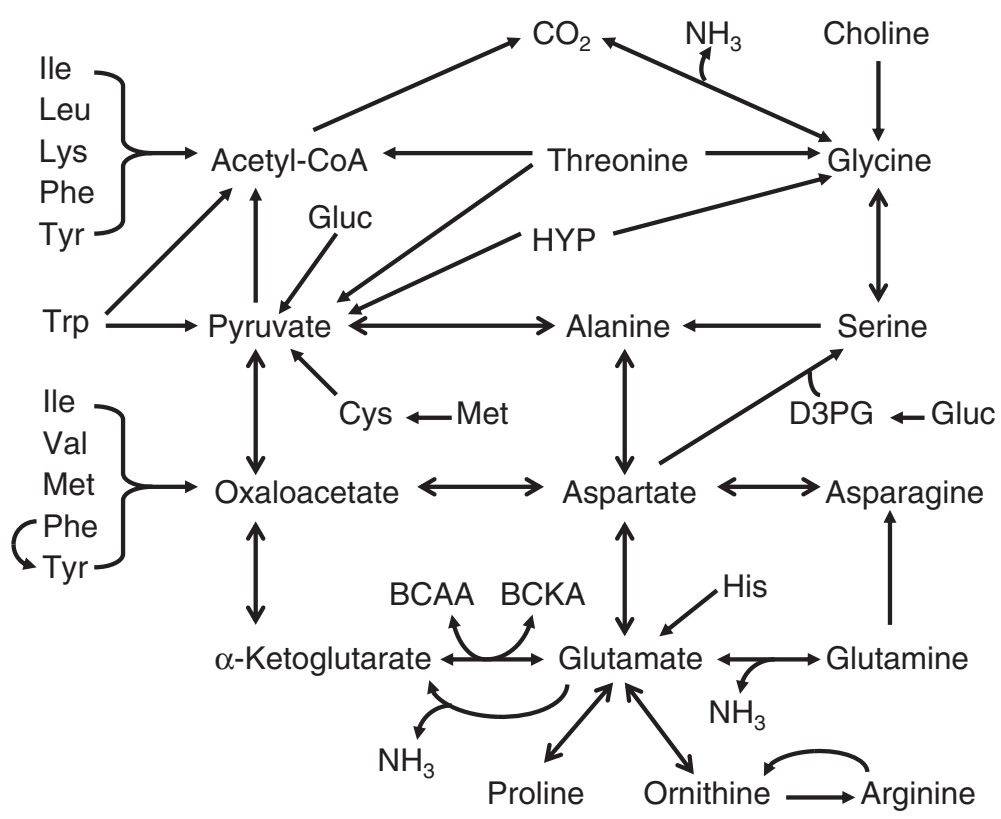

Figure 1 Overall catabolism of EAA to form NEAA in swine. Dietary intake of most essential amino acids exceeds their use for protein synthesis in the body. In contrast, the typical corn- and soybean meal-based diet cannot provide sufficient amounts of arginine, aspartate, glutamate, glutamine, glycine, and proline for protein accretion for young pigs, and these amino acids must be synthesized from essential amino acids. BCAA, branched-chain amino acids; BCKA, branched-chain a-ketoacids; D3PG, D-3-phosphoglycerate; Gluc, glucose; HYP, hydroxyproline. 
Table 2 Major metabolites and functions of NEAA in nutrition and metabolism

\begin{tabular}{|c|c|c|}
\hline NEAA & $\begin{array}{l}\text { Metabolites or direct } \\
\text { action }\end{array}$ & Major functions \\
\hline \multirow[t]{2}{*}{ NEAA } & Proteins & Structural components of the body; cell growth, development, and function \\
\hline & Peptides & Hormones, antibiotics, and antioxidants \\
\hline \multirow[t]{3}{*}{ Alanine } & Directly & Inhibition of pyruvate kinase and hepatic autophagy; gluconeogenesis; \\
\hline & & transamination; glucose-alanine cycle; interorgan metabolism and transport of \\
\hline & & both carbon and nitrogen \\
\hline \multirow[t]{10}{*}{ Arginine } & Directly & Activation of MTOR signaling; antioxidant; regulation of hormone secretion; \\
\hline & & allosteric activation of $\mathrm{N}$-acetylglutamate synthase; ammonia detoxification; \\
\hline & & regulation of gene expression; immune function; activation of tetrahydro- \\
\hline & & biopterin synthesis; $N$ reservoir; methylation of proteins \\
\hline & Nitric oxide & Signaling molecule; regulator of nutrient metabolism, vascular tone, \\
\hline & & hemodynamics, angiogenesis, spermatogenesis, embryogenesis, fertility, \\
\hline & & immune function, hormone secretion, wound healing, neurotransmission, \\
\hline & & tumor growth, mitochondrial biogenesis and function \\
\hline & Ornithine & Ammonia detoxification; syntheses of proline, glutamate and polyamines; \\
\hline & & mitochondrial integrity; wound healing \\
\hline \multirow[t]{2}{*}{ Asparagine } & Directly & Cell metabolism and physiology; regulation of gene expression and immune \\
\hline & & function; ammonia detoxification; function of the nervous system \\
\hline \multirow[t]{3}{*}{ Aspartate } & Directly & Purine, pyrimidine, asparagine, and arginine synthesis; transamination; \\
\hline & & urea cycle; activation of NMDA receptors; synthesis of inositol and $\beta$-alanine \\
\hline & D-Aspartate & Activation of NMDA receptors in brain \\
\hline \multirow[t]{3}{*}{ Cysteine } & Directly & Disulfide linkage in protein; transport of sulfur \\
\hline & Taurine & Antioxidant; regulation of cellular redox state; osmolyte \\
\hline & $\mathrm{H}_{2} \mathrm{~S}$ & A signaling molecule to regulate bloo flow, immunity, and neurological function \\
\hline \multirow[t]{5}{*}{ Glutamate } & Directly & Glutamine, citrulline, and arginine synthesis; bridging the urea cycle with the \\
\hline & & $\begin{array}{l}\text { Krebs cycle; transamination; ammonia assimilation; flavor enhancer; activation of NMDA receptors; } \\
\text { N-acetylglutamate synthesis }\end{array}$ \\
\hline & GABA & Inhibitory or excitatory neurotransmitter depending on region in brain and type \\
\hline & & of receptor; regulation of neuronal excitability of throughout the nervous \\
\hline & & system; modulation of muscle tone; inhibition of T-cell response and inflammation \\
\hline \multirow[t]{7}{*}{ Glutamine } & Directly & Regulation of protein turnover through cellular MTOR signaling, gene \\
\hline & & expression, and immune function; a major fuel for rapidly proliferating cells; \\
\hline & & $\begin{array}{l}\text { inhibition of apoptosis; syntheses of purine, pyrimidine, ornithine, citrulline, arginine, proline, and asparagines; } N \\
\text { reservoir ; synthesis of NAD(P) }\end{array}$ \\
\hline & Glu and Asp & Excitatory neurotransmitters; components of the malate shuttle; cell \\
\hline & & Metabolism; ammonia detoxification; major fuels for enterocytes \\
\hline & GlcN6P & Synthesis of aminosugars and glycoproteins; inhibition of nitric oxide synthesis; anti-inflammation; angiogenesis \\
\hline & Ammonia & Renal regulation of acid-base balance; synthesis of glutamate and carbamoyl- phosphate \\
\hline \multirow[t]{3}{*}{ Glycine } & Directly & $\begin{array}{l}\text { Calcium influx through a glycine-gated channel in the cell membrane; purine and serine synthesis; synthesis of } \\
\text { porphyrins; inhibitory neurotransmitter in the central nervous system; co-agonist with glutamate for }\end{array}$ \\
\hline & & NMDA receptors; antioxidant; anti-inflammation; one-carbon-unit metabolism \\
\hline & Heme & $\begin{array}{l}\text { Hemoproteins (e.g., hemoglobin, myoglobin, catalase, and cytochrome c); } \\
\text { production of carbon monoxide (a signaling molecule) }\end{array}$ \\
\hline \multirow[t]{3}{*}{ Proline } & Directly & Collagen structure and function; neurological function; osmoprotectant; \\
\hline & & activation of MTOR; a sensor of cellular energy status; an antioxidant; \\
\hline & & a regulator of the differentiation of cells (including embryonic stem cells) \\
\hline
\end{tabular}


Table 2 Major metabolites and functions of NEAA in nutrition and metabolism (Continued)

\begin{tabular}{|c|c|c|}
\hline & $\mathrm{H}_{2} \mathrm{O}_{2}$ & Killing pathogens; intestinal integrity; a signaling molecule; immunity \\
\hline & P5C & Cellular redox state; DNA synthesis; lymphocyte proliferation; ornithine, \\
\hline & & citrulline, arginine and polyamine synthesis; gene expression; stress response \\
\hline & $\mathrm{OH}$-proline & Structure and function of collagen \\
\hline \multirow[t]{7}{*}{ Serine } & Directly & One-carbon-unit metabolism; syntheses of cysteine, purine, pyrimidine, \\
\hline & & ceramide and phosphatidylserine; synthesis of tryptophan in bacteria; \\
\hline & & gluconeogenesis (particularly in ruminants); protein phosphorylation \\
\hline & Glycine & Many metabolic and regulatory functions \\
\hline & Choline & A component of acetylcholine (a neurotransmitter), phosphatidylcholine (a \\
\hline & & structural lipid in the membrane), betaine (a methyl donor in the one-carbon- unit metabolic pathways) \\
\hline & D-Serine & Activation of NMDA receptors in brain \\
\hline \multirow[t]{6}{*}{ Tyrosine } & Directly & Protein phosphorylation, nitrosation, and sulfation \\
\hline & Dopamine & Neurotransmitter; regulation of immune response \\
\hline & EPN \& NEPN & Neurotransmitters; cell metabolism \\
\hline & Melanin & Antioxidant; inhibition of the production of inflammatory cytokines and \\
\hline & & superoxide; immunity; energy homeostasis; sexual activity; stress response \\
\hline & T3 and T4 & Regulation of energy and protein metabolism, as well as growth \\
\hline $\begin{array}{l}\text { Cys, Glu \& } \\
\text { Gly }\end{array}$ & Glutathione & $\begin{array}{l}\text { Free radical scavenger; antioxidant; cell metabolism (e.g., formation of } \\
\text { leukotrienes, mercapturate, glutathionylspermidine, glutathione-nitric oxide } \\
\text { adduct and glutathionylproteins); signal transduction; gene expression; apoptosis; cellular redox; } \\
\text { immune response }\end{array}$ \\
\hline $\begin{array}{l}\text { Gln, Asp \& } \\
\text { Gly }\end{array}$ & Nucleic acids & $\begin{array}{l}\text { Coding for genetic information; gene expression; cell cycle and function; protein and uric acid synthesis; } \\
\text { lymphocyte proliferation }\end{array}$ \\
\hline
\end{tabular}

EPN, epinephrine; GABA, $\gamma$-Aminobutyrate; GICN6P, glucosamine-6-P; HMB, $\beta$-hydroxy- $\beta$-methylbutyrate; MTOR, mechanistic target of rapamycin; NEPN, norepinephrine; NOS, nitric oxide synthase; $T_{3}$, triiodothyronine; $T_{4}$, thyroxine.

amino acids except arginine and, therefore, they must be provided in the diet. Conversely, the amino acids that can be synthesized in the body are termed nutritionally dispensable or nonessential, including alanine, asparagine, aspartate, cysteine, glutamate, glutamine, glycine, proline, serine, and tyrosine. NEAA and their metabolites have many physiological functions (Table 2). Cysteine, glutamate, glutamine, glycine, proline and tyrosine are currently considered as conditionally essential amino acids, because they are synthesized insufficiently by animals at certain developmental stages (e.g., the neonatal period) or under certain feeding conditions (corn- and soybean meal-based diets for weanling pigs).

The main function of dietary amino acids is to synthesize tissue proteins in animals. Additionally, individual amino acids have been proposed to act as signaling molecules that regulate mRNA translation. For example, leucine can stimulate protein synthesis in cells by enhancing the phosphorylation of MTOR and its downstream target proteins [16]. Almost all of the amino acids have been implicated to affect directly or indirectly immune function [12] and some are important precursors for the synhesis of neurotransmitters (e.g., $\gamma$-aminobutyrate, dopamine, and serotonin) and certain hormones (e.g., melatonin and thyroxine) in animals $[3,17]$.
Sow's colostrum and milk contain large amounts of glutamate and glutamine (about 20\% of total amino acids), but a negligible amount of ornithine and citrulline [18]. Glutamate actively participates in the transamination reactions of amino acids and is readily converted into many amino acids in swine [3]. Glutamate is an immediate precursor for glutamine synthesis in skeletal muscle, heart, liver, adipose tissue, and brain [17]. Dietary glutamate is catabolized almost completely in the small intestine of piglets to yield ATP, $\mathrm{CO}_{2}$, proline ornithine, citrulline, and arginine [19]. Concentrations of proline and alanine are relatively high in the piglet's plasma compared with glutamate. Glutamate and acetyl-CoA are substrates for synthesis of $\mathrm{N}$-acetylglutamate within liver and enterocytes, therefore up-regulating ammonia detoxification and arginine synthesis [20,21].

Glutamine is utilized by the enterocytes of the small intestine as another major energy substrate [22]. Glutamine could contribute more ATP to pig enterocytes than glucose and fatty acids [23]. Wu et al. (1995) reported that glutamine is a major substrate for synthesis of citrulline and arginine in enterocytes of piglets from the day of birth until seven days of age, and suggested that the endogenous synthesis of arginine is important for the animal's optimal growth and development particularly 
during the neonatal period when requirements for arginine are much higher than its provision from milk [23]. Glutamine is also an essential substrate for the synthesis of glucosamine-6-phopshae, which is utilized for the tion of all aminosugars and glycoproteins in cells. Additionally, glutamine is required for the functions of monocytes, macrophages, lymphocytes, and neutrophils [24]. Thus, high concentrations of glutamine in the plasma help piglets sustain the normal activity of lymphoid organs and the immune system. Taken together, these results indicate that glutamine is a nutritionally essential amino acids for young pigs [10].

Arginine is generally considered nutritionally essential for neonates, because its synthesis is inadequate for metabolic needs [25]. Notably, arginine is the most abundant nitrogen carrier in tissue protein and is a major factor regulating maximal growth of young mammals [26,27]. Formation of physiological levels of nitric oxide from arginine has an anti-inflammatory role in the gastrointestinal tract, whereas relatively large amounts of nitric oxide produced by inducible nitric-oxide synthase kill various kinds of pathogenic microorganisms [12]. Besides serving as a major vasodilator, NO regulates energy metabolism and, therefore, white-fat accretion in the body [8]. Finally, through the synthesis of polyamines and protein, arginine promotes the proliferation of monocytes and lymphocytes, as well as the development of $\mathrm{T}$ helper cells [28].

Proline was not considered by some researchers as an EAA for young pigs $[29,30]$. This was based on the findings under certain experimental conditions that there was no difference in piglet growth performance between prolinefree and proline-supplemented diets [31] likely due to inadequate provision of several limiting amino acids in the basal diet. However, young pigs (e.g., those weighing 1 to $5 \mathrm{~kg}$ ) are unable to synthesize sufficient proline to meet their requirements [32]. Thus, supplementing $1 \%$ proline to the diet for postweaning pigs enhanced intestinal and wholebody growth [13]. Therefore, dietary proline is necessary for maximum growth and development of young pigs.

Cysteine and tyrosine, like glutamate, glutamine and proline, are conditionally essential amino acids for young pigs, particularly under stressful conditions. Cysteine is generated from the catabolism of methionine via the transsulfuration pathway in the liver. Published studies have shown that cysteine can reduce the dietary need for its precursor, methionine, and can satisfy approximately $50 \%$ of the need for total sulfur amino acids [33]. Various tissues and cells release cysteine under catabolic conditions, and this amino acid is required for the synthesis of glutathione in all cell types, including immunocytes

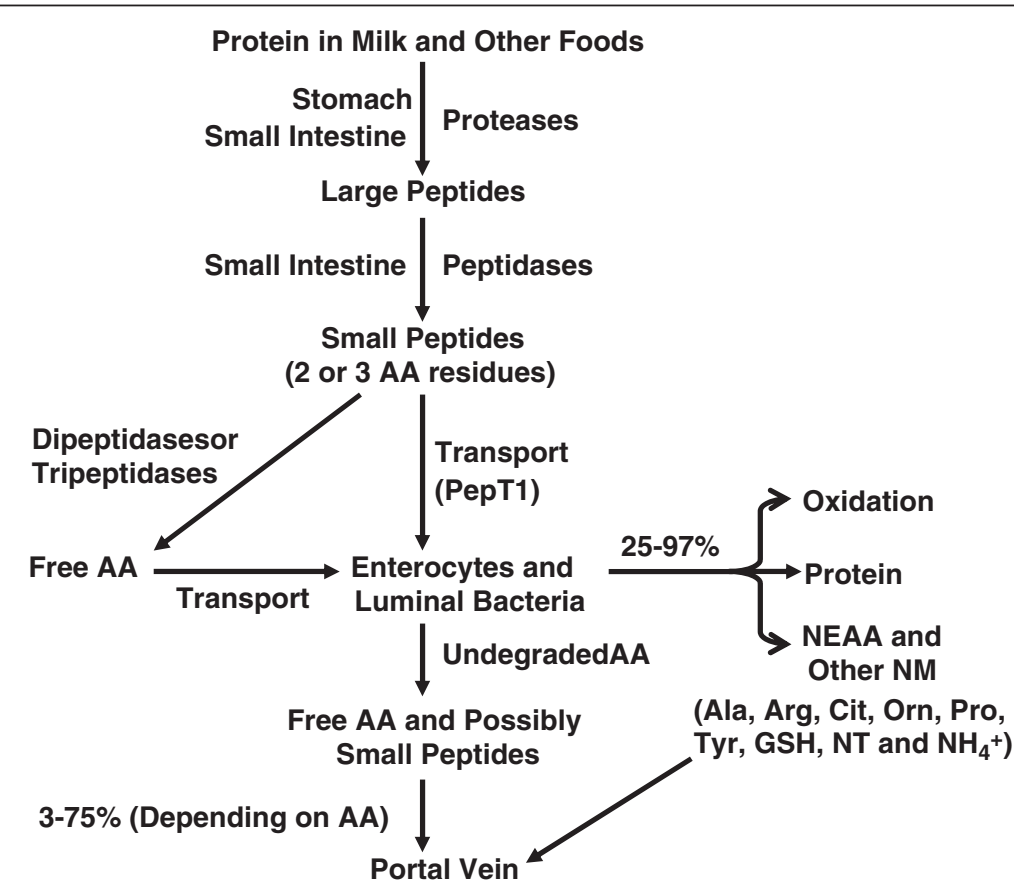

Figure 2 Digestion of dietary protein in the gastrointestinal tract of young pigs. pH values in the gastric (stomach) juice of neonatal pigs and postweaning growing pigs are 3 to 5 and 2 to 3, respectively. $\mathrm{pH}$ values in the lumen of the small intestine of young pigs are 6 to 7 . All dietderived AA undergo various degrees of catabolism by luminal bacteria and some of them are oxidized by enterocytes. $\mathrm{AA}=\mathrm{amino}$ acids; $\mathrm{GSH}=$ glutathione; NEAA = nutritionally nonessential $\mathrm{AA} ; \mathrm{NM}=$ nitrogenous metabolites; $\mathrm{NT}=$ nucleotides; $\mathrm{PepT} 1=\mathrm{H}^{+}$gradient-driven peptide transporter 1. 
[34]. Tyrosine synthesis must depend on the dietary availability of phenylalanine that cannot be synthesized by the animal organism. Clearly, pigs fed low-protein diets cannot produce sufficient quantities of cysteine and tyrosine.

\section{Digestion of dietary protein in young pigs}

The digestion of dietary protein starts in the gastric lumen, continues in the small intestinal lumen, and is completed at the brush-border membrane of the enterocytes (Figure 2). Hydrochloric acid and gastric proteases initiate protein hydrolysis in the lumen of the stomach. Hydrochloric acid is secreted by the gastric parietal cells and functions to activate gastric proteases and denature dietary proteins. The gastric secretory capacity is increased more rapidly after pigs are fed a creep diet rather than nursed by sows [35]. The low capacity of gastric secretion at birth may relate to immaturity of the parietal cells in piglets. The acidity of gastric contents in the post absorptive state is about $\mathrm{pH} 3$ to 5 in milk-fed piglets during the early postnatal period due to low gastric secretory capacity and the high buffering capacity of sow's milk.

Gastric proteases are secreted by the chief cells in the gastric gland. Pepsin A, pepsin B, pepsin C, and chymosin are four critical proteases for protein digestion. Chymosin has strong milk-clotting ability but weak proteolytic

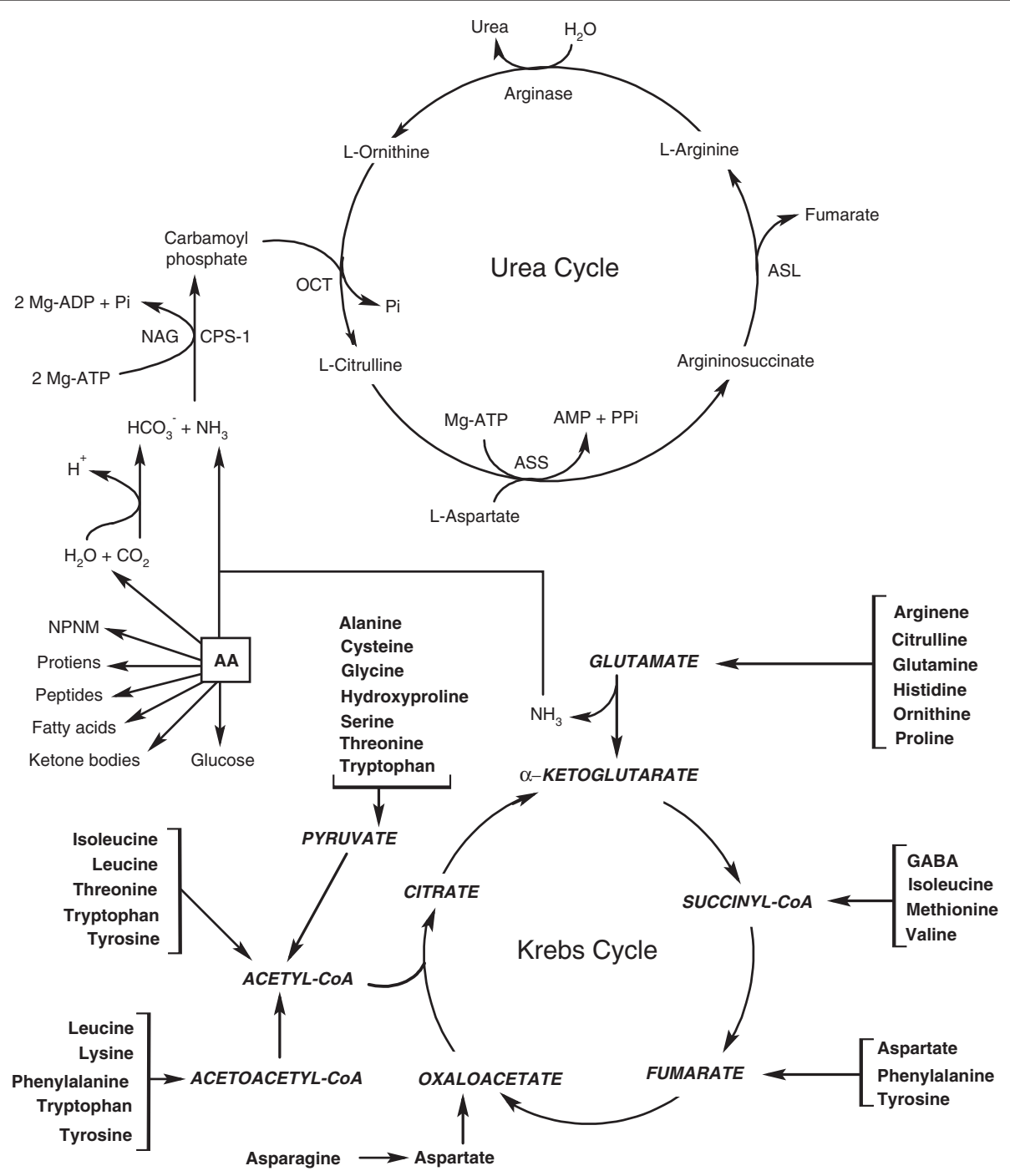

Figure 3 Oxidation of amino acid-derived acetyl-CoA to water and $\mathrm{CO}_{2}$ via the Krebs cycle and the role of the urea cycle to synthesize urea from ammonia in pigs. In animals, amino acids are utilized to produce proteins (including enzymes), small peptides, other nitrogenous metabolites (e.g., nitric oxide, creatine, carnitine, and ammonia), fatty acids, and glucose. Ammonia plays an important role in bridging the Krebs cycle with the urea cycle. AA, amino acids; ASL, argininosuccinate lyase; ASS, argininosuccinate synthase; CPS-1, carbamoylphosphate synthetase-l; GABA, y-aminobutyrate; NAG, N-acetylglutamate; NPNM, non-peptide nitrogenous metabolites; and OCT, ornithine carbamoyltransferase. 
activity. Clotting milk by chymosin occurs through a specific cleavage of $\mathrm{k}$-casein. Milk-clotting may regulate gastric emptying and stimulate gastric development through gastric distention [36]. Prochymosin has the highest concentration at the time of birth. The concentration of prochymosin in the fetal pig stomach is detected as early as at day 80 of gestation [37] and this protein is cleaved to form a biologically active enzyme.

Pepsinogen A replaces the prochymosin to become the dominant protease in the gastric tissue of pigs by the $5^{\text {th }}$ week of age. The proteolytic activity of neonatal piglets is relatively low in the stomach due to gastric acid secretory capacity and the small amount of pepsinogen A secreted. The bioactive compounds, such as immunoglobulins, hormones, growth factors, and bioactive polypeptides present in the colostrum and milk are able to pass the stomach undegraded into the lumen of the small intestine because of the low gastric proteolytic activity toward these proteins and polypeptides. Therefore, postnatal gastrointestinal development in neonatal pigs possibly could be regulated by those bioactive compounds [38].

The pancreas also secretes many types of proteases, including trypsin, chymotrypsin, elastase, as well as carboxypeptidases A and B. Pancreatic proteases are secreted as proenzymes and are activated in the lumen of the small intestine. In the starter phase of feeding, protein digestion in the small intestine begins when the activated pancreatic proteases in the lumen of the small intestine cleave peptide bonds on the carboxyl side of amino acids. Carboxypeptidases remove a single amino acid from the carboxyl-terminal end of proteins and peptides. Oligopeptides generated by gastric and pancreatic proteases are further digested by membrane-bound peptidases to yield free amino acids or di- and tri-peptides before being absorbed into the enterocytes. Aminopeptidase $\mathrm{N}$ is the most abundant membrane-bound peptidase that cleaves amino acids from the N-terminus of oligopeptides.

\section{Absorption of amino acids by the small intestine of young pigs}

Absorption of amino acids by the pig small intestine mainly occurs in the proximal region of the small intestine [39]. Intestinal mucosal cells absorb amino acids via active transport, simple diffusion, and facilitated diffusion. There are at least four sodium-dependent amino acid transporters in the luminal apical membrane of the intestinal mucosal cells that are responsible for transporting amino acids from the lumen of the small intestine into the cytoplasm [40]. After amino acids are absorbed into the enterocytes, they are utilized for either the synthesis of proteins (including enzymes) and other nitrogenous metabolites (e.g., nitric oxide and glutathione) or oxidation via the Krebs cycle to water and $\mathrm{CO}_{2}$ yielding ATP (Figure 3). Amino acids that enter the portal circulation are available for use by extraintestinal tissues, including the liver, cells of the immune system, skeletal muscle, heart, kidneys, brain, and adipose tissue. Excessive amounts of amino acids are converted into urea primarily via the urea cycle (Figure 3 ). Note that ammonia bridges the Krebs cycle with the urea cycle.

Within the first three days after birth, the enterocyte lining the villi in the proximal region of the small intestine can absorb intact immunoglobulins from sow's colostrum, with the highest activity occurring within $24 \mathrm{~h}$ of the postnatal life [41]. The capacity for macromolecular absorption is very important in newborn pigs, which rely on passive immunity from the colostral antibodies. The fetal type of enterocytes responsible for macromolecular uptake is present at birth. Nineteen days after birth, the fetal type of enterocytes change to the adult type of enterocytes, which have the capacity to actively digest and absorb nutrients in the solid form of food [42]. From 24 to $36 \mathrm{~h}$ after birth, the transfer of macromolecules from the intestinal epithelium into the blood is decreased dramatically [43]. Gut closure is associated with the postnatal replacement of fetal intestinal enterocyte with the more mature cells that are incapable of internalizing macromolecules. The mucosal cells of newborn pigs have a longer turnover time than 7- to 14-day-old suckling pigs because the small intestine of the younger pigs has longer villi. Damaged villi in the small intestine of neonatal pigs are replaced with new villi at a faster rate than fetal-type villi.

The large intestine has a limited ability to absorb amino acids and small peptides that are either present in its lumen or from arterial blood. The proximal colon and the cecum in piglets have villus-like structures that are lined with the columnar epithelium, and the epithelium exhibits well-defined mircrovilli on the luminal border. As piglets grow older, their intestinal villus structures are replaced by the relatively flat ones at the mucosal surface [44]. The morphological changes coincide with the transient ability of the large intestine of piglets to absorb a small amount of amino acids [45]. Darragh et al. (1994) reported that the capacity of the proximal colon to absorb amino acids is reduced to an insignificant level by the age of 15 days [46].

\section{Bioavailability of dietary amino acids to extraintestinal tissues in young pigs}

In sow-reared piglets, nearly $100 \%$ of peptide-bound amino acids in milk proteins are hydrolyzed in the gastrointestinal tract [13]. In postweaning pigs, true ileal digestibilities of amino acids in animal- and plant-proteins are $80 \%$ to $90 \%$ and $70 \%$ to $85 \%$, respectively [13]. Undigested amino acids are used by microbes in the small intestine or enter the large intestine $[47,48]$. Absorbed amino acids are not fully available for the synthesis of proteins, peptides and other nitrogenous products in extra-intestinal tissues, 
Table 3 Composition of total AA in food ingredients (\%, as-fed basis) ${ }^{1}$

\begin{tabular}{|c|c|c|c|c|c|c|c|c|c|c|c|c|c|}
\hline AA & $\begin{array}{l}\text { Blood } \\
\text { meal }\end{array}$ & Casein & $\begin{array}{l}\text { Corn } \\
\text { grain }\end{array}$ & CSM & $\begin{array}{l}\text { Feather } \\
\text { meal }\end{array}$ & $\begin{array}{l}\text { Fish } \\
\text { meal }\end{array}$ & Gelatin & MBM & $\begin{array}{l}\text { Peanut } \\
\text { meal }\end{array}$ & PBM & SBM & $\begin{array}{l}\text { SBM } \\
\text { (DH) }\end{array}$ & $\begin{array}{l}\text { Sorghum } \\
\text { grain }\end{array}$ \\
\hline $\mathrm{DM}$ & 91.8 & 91.7 & 89.0 & 90.0 & 95.1 & 91.8 & 89.0 & 96.1 & 91.8 & 96.5 & 89.0 & 96.4 & 89.1 \\
\hline $\mathrm{CP}$ & 89.6 & 88.0 & 9.3 & 40.3 & 82.1 & 63.4 & 100.1 & 52.0 & 43.9 & 64.3 & 43.6 & 51.8 & 10.1 \\
\hline $\mathrm{TP}$ & 88.3 & 86.2 & 8.2 & 32.5 & 81.0 & 63.7 & 97.4 & 50.7 & 35.1 & 60.4 & 38.2 & 41.6 & 8.8 \\
\hline Ala & 7.82 & 2.77 & 0.71 & 1.42 & 4.18 & 5.07 & 9.01 & 4.78 & 1.86 & 4.91 & 1.95 & 2.08 & 0.96 \\
\hline Arg & 4.91 & 3.40 & 0.38 & 4.54 & 5.74 & 4.85 & 7.68 & 3.67 & 5.68 & 4.63 & 3.18 & 3.12 & 0.41 \\
\hline Asn & 4.67 & 2.56 & 0.35 & 1.57 & 1.67 & 2.92 & 1.42 & 2.21 & 1.80 & 2.73 & 2.10 & 2.42 & 0.31 \\
\hline Asp & 6.20 & 3.88 & 0.43 & 1.94 & 2.92 & 4.34 & 2.87 & 3.07 & 2.52 & 4.10 & 3.14 & 3.40 & 0.36 \\
\hline Cys & 1.92 & 0.43 & 0.20 & 0.70 & 4.16 & 0.67 & 0.05 & 0.49 & 0.65 & 1.05 & 0.70 & 0.69 & 0.19 \\
\hline Gln & 4.32 & 11.2 & 1.02 & 3.81 & 2.86 & 3.94 & 3.03 & 2.81 & 2.66 & 3.54 & 3.80 & 4.11 & 0.85 \\
\hline Glu & 6.38 & 9.38 & 0.64 & 4.39 & 4.81 & 6.01 & 5.26 & 4.05 & 4.18 & 4.89 & 4.17 & 4.53 & 1.18 \\
\hline Gly & 3.86 & 1.86 & 0.40 & 2.12 & 8.95 & 6.58 & 33.6 & 8.67 & 3.17 & 9.42 & 2.30 & 2.72 & 0.39 \\
\hline His & 5.57 & 2.78 & 0.23 & 1.08 & 0.88 & 1.51 & 0.74 & 1.19 & 0.95 & 1.30 & 1.13 & 1.15 & 0.23 \\
\hline Hyp & 0.51 & 0.14 & 0.00 & 0.05 & 4.95 & 1.86 & 12.8 & 2.88 & 0.07 & 3.31 & 0.08 & 0.07 & 0.00 \\
\hline Ile & 2.54 & 4.91 & 0.34 & 1.19 & 3.79 & 3.26 & 1.17 & 1.92 & 1.41 & 2.32 & 2.03 & 2.10 & 0.38 \\
\hline Leu & 11.4 & 8.82 & 1.13 & 2.26 & 6.75 & 5.24 & 2.61 & 3.56 & 2.48 & 4.21 & 3.44 & 3.70 & 1.21 \\
\hline Lys & 8.25 & 7.49 & 0.25 & 1.66 & 2.16 & 5.29 & 3.75 & 3.16 & 1.37 & 3.44 & 2.80 & 2.87 & 0.22 \\
\hline Met & 1.16 & 2.64 & 0.21 & 0.66 & 0.75 & 2.02 & 1.03 & 1.10 & 0.47 & 1.39 & 0.60 & 0.64 & 0.20 \\
\hline Phe & 5.83 & 4.87 & 0.46 & 2.02 & 3.95 & 2.78 & 1.67 & 1.85 & 1.93 & 2.36 & 2.21 & 2.44 & 0.51 \\
\hline Pro & 6.29 & 10.8 & 1.06 & 1.89 & 11.8 & 4.25 & 20.6 & 5.86 & 2.30 & 6.72 & 3.05 & 3.18 & 0.96 \\
\hline Ser & 4.49 & 5.08 & 0.45 & 1.72 & 8.80 & 2.80 & 3.44 & 2.08 & 2.03 & 2.67 & 2.12 & 2.35 & 0.46 \\
\hline Trp & 1.30 & 1.24 & 0.07 & 0.44 & 0.80 & 0.70 & 0.22 & 0.39 & 0.38 & 0.49 & 0.62 & 0.63 & 0.10 \\
\hline Thr & 3.95 & 4.10 & 0.31 & 1.25 & 3.97 & 4.11 & 3.45 & 2.42 & 1.67 & 2.85 & 1.76 & 2.03 & 0.32 \\
\hline Tyr & 2.86 & 5.06 & 0.43 & 1.10 & 2.04 & 2.36 & 0.93 & 1.45 & 1.39 & 1.84 & 1.66 & 1.72 & 0.45 \\
\hline Val & 8.21 & 6.03 & 0.44 & 1.69 & 5.76 & 3.80 & 1.96 & 2.23 & 1.70 & 2.89 & 2.09 & 2.25 & 0.50 \\
\hline
\end{tabular}

Adapted from Li et al. [50]. Molecular weights of intact AA were used to calculate the content of peptide-bound AA in feed ingredients. Except for fish meal which contains $1.4 \%$ free amino acids ( $\mathrm{g} / 100 \mathrm{~g}$ sample), total free amino acids account for less than $1 \%$ of total amino acids in other ingredients.

$C P=$ crude protein; $C S M=$ cottonseed meal; $D H=$ dehulled; Hyp, hydroxyproline; $M B M=$ meat and bone meal; $P B M=$ poultry byproduct meal; $S B M=$ soybean meal $\mathrm{TP}=$ true protein.

because some of them undergo irreversible catabolism to water and $\mathrm{CO}_{2}$ [30]. Formulation of a highly efficient diet requires knowledge about the bioavailability of amino acids in animals. This is assessed by the true ileal digestibility measured at the end of the small intestine after corrections for flows of endogenous (both basal and diet-specific) amino acids into its lumen [47]. Apparent ileal digestibility, which is a more accurate approach than fecal digestibility [48], is measured at the end of the small intestine without consideration of the endogenous or exogenous origin of the indigestible nitrogen or amino acids, therefore underestimating the true digestibility of dietary protein. As a consequence, a low-protein diet is undervalued to a greater extent than a high-protein diet. Because of technical difficulties in measuring the diet-induced (or diet-specific) flow of endogenous amino acids into the lumen of the small intestine, this component is eliminated in determining the standardized ileal digestibility of amino acids. Values of standardized ileal amino-acid digestibility are intermediate between apparent and true ileal amino-acid digestibilities [49]. The amounts and relative proportions of all amino acids in the diet affect the deposition of protein in pigs.

\section{Dietary requirements of amino acids by young pigs}

Protein deposition in the piglet body is affected by both the quality and the amount of dietary protein. Composition of amino acids in common feedstuffs is shown in Table 3. Relatively high intakes of protein and energy are required by neonatal piglets for sustaining their rapid growth rates. The energy density of the diet could influence the voluntary feed intake of neonatal pigs. To satisfy the requirement for energy, feed intake increases when the dietary energy is low. The gut capacity of neonatal pigs would also limit their feed intake. Piglets may not be able to consume sufficient amounts of a diet with a low energy density to maintain their optimal growth rate. Essential 
amino acids cannot be synthesized by piglets and should be provided in the diet. Therefore, an adequate supply of EAA must be ensured while considering dietary protein requirements.

Current growth models cannot be used to accurately estimate energy or amino acid requirements for neonatal pigs ( $<20 \mathrm{~kg}$ body weight) because there is not sufficient information on their energy or amino acid metabolism. Rather, total dietary lysine required between 3 and $20 \mathrm{~kg}$ of BW has been estimated by equations derived from feeding experiments. This method yields $1.45 \%$ lysine at $5 \mathrm{~kg}, 1.25 \%$ lysine at $10 \mathrm{~kg}, 1.15 \%$ lysine at $15 \mathrm{~kg}$, and $1.05 \%$ lysine at 20 $\mathrm{kg}$ of BW, which is in keeping with a progressive decrease in the fractional rate of skeletal-muscle protein synthesis. Experimental data on optimal dietary requirements of other amino acids by neonatal pigs between birth and weaning are not available. Thus, NRC-recommended intakes of dietary amino acids [30] may not necessarily be ideal for piglets. This is exemplified by dietary requirement of arginine by young pigs [3].

Sow's milk is thought to provide adequate amino acids needed for the growth of neonatal pigs. However, it has been shown that the amount of milk produced by sows during lactation does not provide adequate amounts of all amino acids for supporting maximal growth of piglets [51]. Hodge (1974) and Boyd et al. (1995) demonstrated that the artificially reared neonatal pigs can grow at a rate that is at least $50 \%$ greater than that of sow-reared piglets [52,53]. Beginning at eight days of age, piglets exhibits sub-maximal growth, which may have resulted from inadequate intake of protein or energy from sow's milk [53]. Furthermore, arginine is an EAA for the maximal growth of young mammals, but the ratio of arginine to lysine on a gram basis was $0.35 \pm 0.02$ and $0.97 \pm 0.05$ in sow's milk and seven days old piglets, respectively [27]. There are low levels of arginine in sow's milk and, therefore, neonatal pigs must synthesize substantial amount of arginine to achieve a maximum growth rate. Available evidence shows that endogenous synthesis of arginine in young pigs is inadequate for their maximum growth and that, on a dry matter basis, an ideal, highly digestible diet should contain $2.04 \%$ arginine [3].

\section{Applications of functional amino acids to piglet nutrition Role of dietary L-arginine supplementation in enhancing growth of milk-fed piglets}

As alluded to in the preceding sections, data from artificial rearing systems indicate that the biological potential for growth in piglets averaging at postnatal day 21 is at least $400 \mathrm{~g} /$ day or $\geq 74 \%$ greater than that for sow-reared piglets $(230 \mathrm{~g} / \mathrm{d})$ and that suckling piglets start to exhibit submaximal growth beginning at the second week after birth [53]. Recent studies have shown that arginine deficiency is a major factor limiting maximal growth of milk-fed piglets [25]. Dietary supplementation with $0.2 \%$ and $0.4 \% \mathrm{~L}$-arginine to 7 - to 21 -day-old milk-fed piglets artificially reared on a liquid-milk feeding system increases plasma arginine concentrations (30\% and $61 \%$ ), decreased plasma ammonia levels (20\% and 35\%), and enhances weight gain (28\% and 66\%) in a dosedependent manner [6]. Furthermore, supplementing $1.0 \%$ arginine- $\mathrm{HCl}$ to the diet for lactating sows increased milk production and piglet growth, possibly due to increases in mammary gland angiogenesis and blood flow to the mammary gland [7]. Provision of L-arginine, N-carbamoylglutamate (a metabolically stable activator of intestinal arginine synthesis), or arginine-rich rice protein concentrate to either sowreared or weanling pigs is also highly effective in improving their growth performance and immune function [15,54-56]. These growth-promoting substances are now available to pork producers worldwide.

\section{Dietary L-glutamine supplementation enhances growth and} reduces mortality rate in neonatal pigs

Necrotizing enterocolitis is a major cause of death in neonatal piglets who have experienced intrauterine growth restriction (IUGR) before birth [57]. IUGR piglets are more susceptible to infectious morbidities and have a high rate of mortality [51]. Based on multi-faceted roles of L-glutamine in intestinal physiology, L-glutamine $(1 \mathrm{~g} / \mathrm{kg}$ body weight per day) has been administered orally to IUGR piglets to effectively improve their survival and growth [58]. Intestinal atrophy in weanling piglets is one of the crucial problems in swine nutrition and production. Multiple factors, such as immunological challenges, oxidative stress, apoptosis, inflammation, and insufficient energy provision, contribute to the abnormal digestive tract of young pigs. Results of our research indicated that dietary supplementation with $1 \% \mathrm{~L}-$ glutamine prevented jejunal atrophy during the first week postweaning and increased the gain:feed ratio by $25 \%$ during the second week postweaning [11,59]. In all of these experiments, dietary supplementation with up to $1.12 \%$ L-glutamine (dry matter basis) was safe and caused no signs of sickness or incidences of death in any pigs. Post-weaning pigs fed a milk-based or a corn- and soybean meal-based diet tolerated up to $1.12 \%$ supplemental L-glutamine (calculated on a dry matter basis in the diet) for at least 3 months without any adverse effect or toxicity. These findings led to the commercial development and availability of feed-grade glutamine (AminoGut) by Ajinomoto Co., Inc. for use in swine diets [60].

\section{Effect of dietary L-proline supplementation on the growth of young pigs}

Proline metabolism in pigs differs markedly with developmental stage [61,62]. Endogenous proline is synthesized from arginine and glutamate, but in young mammals inadequacy of these two pathways makes proline an EAA 
$[21,32]$. Compared with the control group, supplementing $0.35,0.7,1.05,1.4$, or $2.1 \% \mathrm{~L}$-proline to a proline-free chemically defined diet containing $0.48 \%$ L-arginine and $2 \%$ L-glutamate dose-dependently improved daily weight gains (from 342 to $411 \mathrm{~g}$ per day) and the feed efficiency (gram feed/gram gain; from 1.66 to 1.35 ) of young pigs, while reducing concentrations of urea in plasma by one-half [63]. Notably, increasing the dietary content of L-proline from 0.0 and $2.1 \%$ enhanced daily nitrogen etention from 1.27 to $1.53 \mathrm{~g} / \mathrm{kg}$ body weight ${ }^{0.75}$ (metabolic weight), indicating that piglets cannot synthesize adequately proline.

\section{Effect of dietary L-glutamate supplementation on the growth of weanling pigs}

Glutamate is particularly abundant in sow's milk to support neonatal growth and development [64]. Because there is no uptake of arterial blood glutamate by the gut, the enteral diet is the primary source of glutamate for enterocytes. In young pigs, the supply of dietary glutamate to the gut is limited after weaning due to a marked reduction of food intake, which is associated with severe intestinal atrophy, inflammation, malabsorption, and death. Most recently, we conducted a series of experiments to determine effects of glutamate in the form of its sodium salt [monosodium glutamate (MSG)] on growth performance in weanling pigs [65]. Feed intake was not affected by dietary supplementation with up to $2 \%$ MSG and was $15 \%$ lower in pigs supplemented with 4\% MSG compared with the 0\% MSG group due to high sodium intake. Compared with the control, dietary supplementation with $1 \%, 2 \%$ and 4\% MSG for 3 wk dose-dependently increased: a) plasma concentrations of glutamate, glutamine, and other amino acids (including lysine, methionine, phenylalanine and leucine) likely due to inhibition of catabolism of these amino acids in the small intestine, b) daily weight gain, and c) feed efficiency in postweaning pigs. At day 7 postweaning, dietary supplementation with $1 \%$ to $4 \%$ MSG also increased jejunal villus height, DNA content, and anti-oxidative capacity. The MSG supplementation dosedependently reduced the incidence of diarrhea during the first week after weaning. All variables in standard hematology and clinical chemistry tests, as well as gross and microscopic structures, did not differ among the five groups of pigs. These results indicate that dietary supplementation with up to $4 \% \mathrm{MSG}$ is safe and improves growth performance in postweaning pigs.

\section{Conclusion and perspectives}

Despite rapid advances in amino acid nutrition over the past decade, efficiency of the utilization of dietary protein by young pigs remains suboptimal as a result of both biochemical and physiological limitations. Such limitations are: [1] the extensive degradation of both EAA and NEAA by the small intestine and extra-intestinal tissues, [2] the obligatory use of amino acids for the production of nonprotein nitrogenous substances, and [3] age-dependent decline in muscle MTOR activity. Furthermore, the traditional classification of amino acids as nutritionally essential or nonessential has major conceptual limitations. It is also unfortunate that the current version of NRC does not recommend dietary requirements of NEAA by neonatal, postweaning, growing-finishing, or gestating pigs because it is thought that the end points for evaluation cannot be easily defined. However, this should not be the case, because the classical approaches to determine dietary requirements of EAA (e.g., growth, lactation, and reproductive performance of animals) can also be applied to NEAA. Recently, important roles for amino acids, particularly glutamine and arginine, in regulating gene expression at both transcriptional and translational levels in animals have been clearly demonstrated. Moreover, both EAA and NEAA have nutritional and regulatory functions in the body [66-70]. Recent progresses in understanding of functional amino acids are transforming the practice of swine nutrition worldwide. Thus, new knowledge about metabolic transformations of amino acids and their physiological roles in cellular signaling has greatly advanced amino acid nutrition and also has important practical implications for enhancing the efficiency of pig production.

\section{Abbreviations \\ AMPK: AMP-activated protein kinase; EAA: Nutritionally essential amino acids; 4EBP1: Eukaryotic translation initiation factor 4E-binding protein-1; IUGR: Intrauterine growth restriction; MSG: Monosodium glutamate; MTOR: Mechanistic or mammalian target of rapamycin; NEAA: Nutritionally nonessential amino acids; NRC: National Research Council.}

\section{Competing interests}

The authors declare that they have no competing interests.

\section{Authors' contributions}

All authors contributed to the writing of this review paper. They read and approved the manuscript for publication.

\section{Acknowledgments}

Work in our laboratories was supported by National Research Initiative Competitive Grants from the Animal Reproduction Program (2008-3520319120) and Animal Growth \& Nutrient Utilization Program (2008-3520618764) of the USDA National Institute of Food and Agriculture, AHA (10GRNT4480020), Texas A\&M AgriLife Research (H-8200), the National Basic Research Program of China (2013CB127302), the National Natural Science Foundation of China $(30810103902,30972156,31172217,31272450$, and 31272451), China Postdoctoral Science Foundation (2012 T50163), Chinese Universities Scientific Funds (2012RC024), and the Thousand-People Talent program at China Agricultural University.

Received: 6 October 2012 Accepted: 19 February 2013

Published: 27 February 2013

\section{References}

1. Baker DH: Comparative nutrition and metabolism: explication of open questions with emphasis on protein and amino acids. Proc Natl Acad SCl 2005, 102:17897-17902.

2. Kim SW, Wu G, Baker DH: Ideal protein and amino acid requirements by gestating and lactating sows. Pig News and Information 2005, 26:89N-99N. 
3. Wu G: Amino acids: metabolism, functions, and nutrition. Amino Acids 2009, 37:1-17.

4. Bergen WG, Wu G: Intestinal nitrogen recycling and utilization in health and disease. J Nutr 2009, 139:821-825.

5. Wu G, Bazer FW, Tuo W, Flynn SP: Unusual abundance of arginine and ornithine in porcine allantoic fluid. Biol Reprod 1996, 54:1261-1265.

6. Kim SW, Wu G: Dietary arginine supplementation enhances the growth of milk-fed young pigs. J Nutr 2004, 134:625-630

7. Mateo RD, Wu G, Moon HK, Carroll JA, Kim SW: Effects of dietary arginine supplementation during gestation and lactation on the performance of lactating primiparous sows and nursing piglets. J Anim Sci 2008, 86:827-835

8. Jobgen WS, Fried SK, Fu WJ, Meininger CJ, Wu G: Regulatory role for the arginine-nitric oxide pathway in metabolism of energy substrates. $J$ Nutr Biochem 2006, 17:571-588

9. Reeds PJ, Burrin DG: Glutamine and the bowel. J Nutr 2001, 131:2505S-2508S

10. Wu G: Functional amino acids in growth, reproduction, and health. Adv Nutr 2010, 1:31-37

11. Wang JJ, Chen LX, Li P, Li XL, Zhou HJ, Wang FL, Li DF, Yin YL, Wu G: Gene expression is altered in piglet small intestine by weaning and dietary glutamine supplementation. J Nutr 2008, 138:1025-1032.

12. Li $P$, Yin $Y L$, Li DF, Kim SW, Wu G: Amino acids and immune function. $B r$ J Nutr 2007, 98:237-252.

13. Wu G, Bazer FW, Burghardt RC, Johnson GA, Kim SW, Li XL, Satterfield MC, Spencer TE: Impacts of amino acid nutrition on pregnancy outcome in pigs: mechanisms and implications for swine production. J Anim Sci 2010, 88:E195-E204.

14. $\mathrm{Wu} G$, Meininger $\mathrm{CJ}$ : Regulation of nitric oxide synthesis by dietary factors. Annu Rev Nutr 2002, 22:61-86.

15. Li XL, Bazer FW, Gao HJ, Jobgen WJ, Johnson GA, Li P, McKnight JR, Satterfield MC, Spencer TE, Wu G: Amino acids and gaseous signaling. Amino Acids 2009, 37:65-78.

16. Anthony JC, Anthony TG, Kimball SR, Vary TC, Jefferson LS: Orally administered leucine stimulates protein synthesis in skeletal muscle of postabsorptive rats in association with increased elF4F formation. $J$ Nutr 2000, 130:139-145.

17. Heger J: Essential to non-essential amino acid ratios. In Amino Acids in Animal Nutrition. Edited by D'Mello JPF. Edinburgh, UK: CABI Publishing; 2003:103-204

18. Wu G, Knabe DA: Free and protein-bound amino acids in sow's colostrum and milk. J Nutr 1994, 124:415-424.

19. Wu G: Intestinal mucosal amino acid catabolism. J Nutr 1998, 128:1249-1252.

20. Meijer AJ, Lamers WH, Chamuleau RA: Nitrogen metabolism and ornithine cycle function. Physiol Rev 1990, 70:701-748

21. Wu G, Morris SM Jr: Arginine metabolism: nitric oxide and beyond. Biochem J 1998, 336:1-17.

22. Wu G, Knabe DA, Flynn NE: Synthesis of citrulline from glutamine in pig enterocytes. Biochem J 1994, 299:115-121.

23. Wu G, Knabe DA, Yan W, Flynn NE: Glutamine and glucose metabolism in enterocytes of the neonatal pig. Am J Physiol 1995, 268:R334-R342.

24. Alverdy JC: Effects of glutamine-supplemented diets on immunology of the gut. JPEN 1990, 14:109S-113S

25. Wu G, Knabe DA, Kim SW: Arginine nutrition in neonatal pigs. J Nutr 2004, 134:2783S-2790S

26. Flynn NE, Meininger CJ, Haynes TE, Wu G: The metabolic basis of arginine nutrition and pharmacotherapy. Biomed Pharmacother 2002, 56:427-438.

27. Wu G, Ott TL, Knabe DA, Bazer FW: Amino acid composition of the fetal pig. J Nutr 1999, 129:1031-1038.

28. Suchner $U$, Heyland DK, Peter $K$ : Immune-modulatory actions of arginine in the critically ill. Br J Nutr 2002, 87:S121-S132.

29. Chung TK, Baker DH: A note on the dispensability of proline for weanling pigs. Anim Prod 1993, 56:407-408

30. National Research Council (NRC): Nutrient Requirements of Swine. 11th edition. Washington DC, USA: National Academy Press; 2012.

31. Murphy JM, Murch SJ, Ball RO: Proline is synthesized from glutamate during intragastric infusion but not during intravenous infusion in neonatal piglets. J Nutr 1996, 126:878-886.

32. Ball RO, Atkinson JL, Bayley HS: Proline as an essential amino acid for the young pig. Br J Nutr 1986, 55:659-668.
33. Chung TK, Baker DH: Utilization of methionine isomers and analogs by the pig. Can J Anim Sci 1992, 72:185-188.

34. Mosenthin $\mathrm{R}$, Rademacher M: Digestible amino acids in diet formulation for pigs. In Amino Acids in Animal Nutrition. Edited by D'Mello JPF. Edinburgh, UK: CABI Publishing; 2003:169-186.

35. Cranwell PD, Noakes DE, Hill KJ: Gastric secretion and fermentation in the suckling pig. Br J Nutr 1976, 36:71-86.

36. Stadaas J, Schrumpf E: Intragastric pressure-volume relationship and gastrin release after distention of separate parts of the stomach. Scand J Gastroenterol 1974, 9:781-785.

37. Sangild T, Silver M, Fowden AL, Turvey A, Foltmann B: Adrenocortical stimulation of stomach development in the prenatal pig. Biol Neonate 1994, 65:378-389.

38. Xu RJ, Wang F, Zhang SH: Postnatal adaptation of the gastrointestinal tract in neonatal pigs: a possible role of milk-borne growth factors. Livest Prod Sci 2000, 66:95-107

39. Buraczewska $L$ : Absorption of amino acids in different parts of the small intestine in growing pigs. III. Absorption of constituents of protein hydrolysates. Acta Physiol Polonica 1981, 32:569-584.

40. Herdt T: Digestion and absorption: the nonfermentative processes. In Textbook of Veterinary Physiology. Edited by Cunningham JG. Philadelphia, PA: W. B. Saunders; 1992:316-344

41. Baintner K: Intestinal Absorption of Macromolecules and Immune Transmission from Mother to Young. Boca Raton, Florida: CRC Press; 1986.

42. Smith MW, Peacock MA: "M" cell distribution in follicle-associated epithelium of mouse Peyer's patch. Am J Anat 1980, 159:167-175.

43. Ekstrom GM, Westrom BR: Cathepsin B and D activities in intestinal mucosa during postnatal development in pigs. Relation to intestinal uptake and transmission of macromolecules. Biol Neonate 1991, 59:314-321.

44. Xu RJ, Mellor DJ, Tungthanathanich P, Birtles MJ, Reynolds GW, Simpson HV: Growth and morphological changes in the small and the large intestine in piglets during the first three days after birth. J Dev Physiol 1992, 18:161-172

45. James PS, Smith MW: Methionine transport by pig colonic mucosa measured during early post-natal development. J Physiol 1976, 262:151-168.

46. Darragh AJ, Cranwell PD, Moughan PJ: Absorption of lysine and methionine from the proximal colon of the piglet. Br J Nutr 1994, 71:739-752.

47. Low AG: Digestibility and availability of amino acids from feedstuffs for pigs: a review. Livest Prod Sci 1982, 9:511-520.

48. Kong XF, Yin YL, He QH, Yin FG, Liu HJ, Li TJ, Huang RL, Geng MM, Ruan Z, Deng ZY, Xie MY, Wu G: Dietary supplementation with Chinese herbal powder enhances ileal digestibilities and serum concentrations of amino acids in young pigs. Amino Acids 2009, 37:573-582.

49. Stein HH, Sève B, Fuller MF, Moughan PJ, de Lange CF: Amino acid bioavailability and digestibility in pig feed ingredients: terminology and application. J Anim Sci 2007, 85:172-180.

50. Li XL, Rezaei R, Li P, Wu G: Composition of amino acids in feed ingredients for animal diets. Amino Acids 2011, 40:1159-1168.

51. Rezaei R, Knabe DA, Li XL, Feng S, Wu G: Enhanced efficiency of milk utilization for growth in surviving low-birth-weight piglets. J Anim Sci Biotech 2011, 2:73-83.

52. Hodge RW: Efficiency of food conversion and body composition of the preruminant lamb and the young pig. Br J Nutr 1974, 32:113-126.

53. Boyd DR, Kensinger RS, Harrell RJ, Bauman DE: Nutrient uptake and endocrine regulation of milk snthesis by mmmary tssue of Ictating sws. J Anim Sci 1995, 73:36-56.

54. Tan BE, Li XG, Kong XF, Huang RL, Ruan Z, Yao K, Deng ZY, Xie MY, Shinzato I, Yin YL, Wu G: Dietary L-arginine supplementation enhances the immune status in early-weaned piglets. Amino Acids 2009, 37:323-331.

55. Yao K, Yin YL, Chu W, Liu Z, Deng D, Li T, Huang R, Zhang J, Tan B, Wang W, Wu G: Dietary arginine supplementation increases mTOR signaling activity in skeletal muscle of neonatal pigs. J Nutr 2008, 138:867-872.

56. Hou ZP, Yin YL, Huang RL, Li TJ, Hou YQ, Liu YL, Wu X, Liu ZQ, Wang W, Xiong $H$, Wu GY, Tan LX: Rice protein concentrate partially replaces dried whey in the diet for early-weaned piglets and improves their growth performance. J Sci Food Agric 2008, 88:1187-1193.

57. Wu G, Bazer FW, Wallace JM, Spencer TE: Board-invited review: intrauterine growth retardation: implications for the animal sciences. J Anim Sci 2006, 84:2316-2337. 
58. Haynes TE, Li P, Li XL, Shimotori K, Sato H, Flynn NE, Wang JJ, Knabe DA, Wu G: L-Glutamine or L-alanyl-L-glutamine prevents oxidant- or endotoxin-induced death of neonatal enterocytes. Amino Acids 2009, 37:131-142.

59. Wu G, Meier SA, Knabe DA: Dietary glutamine supplementation prevents jejunal atrophy in weaned pigs. J Nutr 1996, 126:2578-2584.

60. Wu G, Bazer FW, Davis TA, Jaeger LA, Johnson GA, Kim SW, Knabe DA, Meininger $C$, Spencer TE, Yin YL: Important roles for the arginine family of amino acids in swine nutrition and production. Livest Sci 2007, 112:8-22.

61. Wu G: Synthesis of citrulline and arginine from proline in enterocytes of postnatal pigs. Am J Physiol Gastrointest Liver Physiol 1997, 272:G1382-G1390

62. Bertolo RF, Burrin DG: Comparative aspects of tissue glutamine and proline metabolism. J Nutr 2008, 138:2032S-2039S.

63. Kirchgessner M, Fickler J, Roth FX: Effect of dietary proline supply on $\mathrm{N}$-balance of piglets. 3. Communication on the importance of nonessential amino acids for protein retention. J Anim Physiol Anim Nutr 1995, 73:57-65.

64. Wu G: Recent advances in swine amino acid nutrition. J Anim Sci Biotech 2010, 1:49-61.

65. Rezaei R, Knabe DA, Tekwe CD, Dahanayaka S, Ficken MD, Fielder SE, Eide SJ, Lovering SL, WU G: Dietary supplementation with monosodium glutamate is safe and improves growth performance in postweaning pigs. Amino Acids 2013, 44:911-923.

66. Xi PB, Jiang ZY, Zheng CT, Lin YC, Wu G: Regulation of protein metabolism by glutamine: implications for nutrition and health. Front Biosci 2011, 16:578-597.

67. Hou YQ, Wang L, Zhang W, Yang ZG, Ding BY, Zhu HL, Liu YL, Qiu YS, Yin YL, Wu G: Protective effects of $\mathrm{N}$-acetylcysteine on intestinal functions of piglets challenged with lipopolysaccharide. Amino Acids 2012, 43:1233-1242.

68. Lei J, Feng DY, Zhang YL, Zhao FQ, Wu ZL, San Gabriel A, Fujishima Y, Uneyama $\mathrm{H}$, Wu G: Nutritional and regulatory role of branched-chain amino acids in lactation. Front Biosci 2012, 17:2725-2739.

69. Tan BE, Li XG, Yin YL, Wu ZL, Liu C, Tekwe CD, Wu G: Regulatory roles for L-arginine in reducing white adipose tissue. Front Biosci 2012, 17:2237-2246

70. Wu G, Wu ZL, Dai ZL, Yang Y, Wang WW, Liu C, Wang B, Wang JJ, Yin YL Dietary requirements of "nutritionally nonessential amino acids" by animals and humans. Amino Acids 2013. doi:10.1007/s00726-012-1444-2.

doi:10.1186/2049-1891-4-7

Cite this article as: Rezaei et al:: Biochemical and physiological bases for utilization of dietary amino acids by young Pigs. Journal of Animal Science and Biotechnology 2013 4:7.

\section{Submit your next manuscript to BioMed Central and take full advantage of:}

- Convenient online submission

- Thorough peer review

- No space constraints or color figure charges

- Immediate publication on acceptance

- Inclusion in PubMed, CAS, Scopus and Google Scholar

- Research which is freely available for redistribution 